\title{
Public Schools of Dorpat District at the Beginning of the Reign of Emperor Alexander the First
}

\author{
Yu. E. Gracheva
}

For citation: Gracheva Yu. E. Public Schools of Dorpat District in the Beginning of the Reign of Emperor Alexander the First. Vestnik of Saint Petersburg University. History, 2021, vol. 66, issue 2, pp. 364376. https://doi.org/10.21638/11701/spbu02.2021.203

The purpose of the article is to show the nature of the relationship between Emperor Alexander I, professor of the University of Dorpat Georg Friedrich Parrot and members of the Ministry of Public Education in the process of discussing the reform of parish schools in the Dorpat educational district at the beginning of the $19^{\text {th }}$ century. Professor Parrot became the author of a project on the establishment of parish schools in the district, and his close friendship with the king made it possible to hope for the approval of his ideas by the minister. However, having received the initial support of the emperor, the Dorpat professor faced resistance from some members of the Main Directorate of Schools who did not want to amend the decisions which had already been adopted, and then the military conflict with France became a serious obstacle to the implementation of the planned transformations. Over the course of two years, Parrot had made changes to the text of the draft three times, but could not achieve the final consent of Alexander I. The author comes to the conclusion that Parrot's desire to get special conditions and partial state maintenance for parish schools of the Dorpat district was unfeasible given the context of the protracted war and the worst financial crisis. The article introduces into scholarship an unpublished correspondence between the emperor and the Dorpat professor, which significantly supplements the idea of the reforms of public education in the first decade of the $19^{\text {th }}$ century.

Keywords: Emperor Alexander I, Professor G. F. Parrot, Ministry of public Education, Dorpat school district, parish schools.

Yulia E. Gracheva - PhD (History), Associate Professor, St. Tikhon's Orthodox University, 23-5A, Novokuznetskaya ul., Moscow, 115184, Russian Federation; g.yuliya@mail.ru

Юлия Евгеньевна Грачева - канд. ист. наук, доц., Православный Свято-Тихоновский гуманитарный университет, Российская Федерация, 115184, Москва, ул. Новокузнецкая, 23-5А; g.yuliya@mail.ru

The article was prepared with the support of the Russian Foundation for Basic Research in the framework of project No. 20-09-00162 "Emperor Alexander I and Professor G. F. Parrot: discussions on the ways of reforming Russia".

Статья подготовлена при поддержке РФФИ в рамках проекта № 20-09-00162 «Император Александр I и профессор Г. Ф. Паррот: дискуссии о путях реформирования России».

(c) St. Petersburg State University, 2021 


\title{
Народные школы Дерптского округа в начале царствования императора Александра Первого
}

\author{
Ю. Е. Грачева
}

Для цитирования: Gracheva Yu.E. Public Schools of Dorpat District at the Beginning of the Reign of Emperor Alexander the First // Вестник Санкт-Петербургского университета. История. 2021. Т. 66. Вып. 2. С.364-376. https://doi.org/10.21638/11701/spbu02.2021.203

Цель статьи - показать характер взаимоотношений между императором Александром I, профессором Дерптского университета Георгом Фридрихом Парротом и сотрудниками Министерства народного просвещения в процессе обсуждения реформы приходских училищ в Дерптском учебном округе в начале XIX в. Отсутствие государственного финансирования приходских школ тормозило их развитие по всей Российской империи. Профессор Паррот стал автором проекта об учреждении приходских училищ в округе, а его дружба с царем позволяла надеяться на одобрение идей со стороны министра народного просвещения П.В.Завадовского. План Паррота предусматривал создание в Дерптском округе двух типов приходских школ: первоначальных, содержащихся помещиками, и собственно приходских училищ, находящихся на казенном содержании. Общий надзор за начальным образованием обеспечивал университет. Однако, получив первоначальную поддержку императора, дерптский профессор столкнулся с сопротивлением некоторых членов Главного правления училищ, не желающих вносить изменения в уже принятые постановления. Уговорить Александра I нарушить установленный порядок и решить вопрос в обход министерства Парроту не удалось. Также серьезным препятствием к осуществлению задуманных преобразований стал военный конфликт с Францией, начавшийся летом 1805 г. На протяжении двух лет Паррот трижды вносил изменения в текст проекта, но так и не смог добиться окончательного согласия Александра I. Автор приходит к выводу, что желание Паррота получить для приходских училищ Дерптского округа особые условия и частичное казенное содержание в условиях затяжной войны и тяжелейшего финансового кризиса было невыполнимо. В научный оборот вводится еще неопубликованная переписка между императором и профессором, которая позволяет существенно дополнить сложившееся в историографии представление о реформах народного просвещения в первом десятилетии XIX в.

Ключевые слова: император Александр I, профессор Г.Ф.Паррот, Министерство народного просвещения, Дерптский учебный округ, приходские училища.

The need for reforms in the field of public education was recognized by Emperor Alexander I from the very first days of his reign. This was insisted on by the tsar's teacher, Swiss F.-C. La Harpe ${ }^{1}$; these issues were discussed at their meetings with members of the Secret Committee ${ }^{2}$. Already on September 8, 1802, the Ministry of Public Education was established, under whose control all educational institutions of the empire were trans-

1 Shil'der N. K. Imperator Aleksandr I, ego zhizn' i tsarstvovanie: v 4 t. T. 2. St. Petersburg, 1897. P. 50; Andreev A. Yu. F.-S. Lagarp i razrabotka reformy narodnogo obrazovaniia v Rossii // Rossiiskaia istoriia. 2010. No. 6. P. 40-46.

2 Zhukovskaia T.N. Prosvetitel'skie proekty «molodykh druzei» i sozdanie Ministerstva narodnogo prosveshcheniia (1802) // Trudy istoricheskogo fakul'teta Sankt-Peterburgskogo universiteta. 2012. No. 11. P. 181-191; Rei M.-P. Aleksandr I. Moscow, 2013. P. 142-145. 
ferred, and by the end of 1804 the main documents had been adopted that determined the structure of universities, gymnasiums, county and parish schools ${ }^{3}$.

Realizing the need for an early transformation and opening of educational institutions in the country, the emperor ordered to allocate annually an amount from the treasury for the maintenance of universities, gymnasiums and county schools. Although the allocated amounts covered only the basic costs of providing schools, for the state this meant a multiple increase in spending on public education. The treasury could not finance parish schools, most of which were only to be created, so their entire maintenance fell on the local nobility and city societies ${ }^{4}$. As a result, as repeatedly noted in historiography, "from the very beginning the creation of parish schools turned out to be more problematic than the foundation of gymnasiums and county schools" . In fact, education of peasant children depended on the desire and ability of the landowners to establish parish schools on their estates, which did not guarantee their imminent spread throughout the empire. For the development of public schools, it was necessary either to develop additional projects in the ministry itself, or to hope for private initiatives of interested nobles.

It was at the time that the professor of physics and the first rector of the University of Dorpat Georg Friedrich Parrot (1767-1852), who became one of the most active participants in the reforms of public education in the Dorpat district in the first decade of the $19^{\text {th }}$ century, emerged in the circle of tsar's advisors. Personal friendship between Parrot and Alexander I arose shortly after their acquaintance in 1802 during a discussion of university jurisdiction ${ }^{6}$. The German scholar repeatedly expressed his views in letters to the emperor on the need for public education through the creation of a network of parish schools ${ }^{7}$. He constantly emphasized that he cared about the neglected majority of the nation ("la majorité la plus négligée de la nation") of the four provinces of the Dorpat school district ${ }^{8}$. If for Russian provinces ("les provinces proprement russes") the part of the charter of educational institutions that concerned parish schools was applicable, then it was "in no way modeled on the physical, moral and civil situation of our peasant", Parrot wrote to the tsar in December 1804. The formation of "the unfortunate Livonian and

${ }^{3}$ Predvaritel'nye pravila narodnogo prosveshcheniia // Sbornik postanovlenii po Ministerstvu narodnogo prosveshcheniia. Vol. 1. St. Petersburg, 1875. P. 13-21; Ustavy Imperatorskikh Moskovskogo, Khar'kovskogo i Kazanskogo universitetov // Ibid. P.295-331; Ustav uchebnykh zavedenii, podvedomykh universitetam // Ibid. P.331-368; Rozhdestvenskii S. V. Istoricheskii obzor deiatel'nosti Ministerstva narodnogo prosveshcheniia. St. Petersburg, 1902. P. 30-74.

${ }^{4}$ Parochial schools "are kept in cities from urban societies, in state-owned villages dependent on parishioners, in landowners' villages by order of landowners". Ustav uchebnykh zavedenii, podvedomykh universitetam. 5 noiabria 1804 goda // Sbornik postanovlenii... \$162. P. 366.

${ }^{5}$ Kuzber Ia. Vospitanie elit i narodnoe obrazovanie v Rossiiskoi imperii XVIII — pervoi poloviny XIX veka. Diskurs, zakonodatel'stvo, real'nost'. Moscow, 2018. P. 360.

${ }^{6}$ Bienemann F. Der Dorpater Professor G. F. Parrot und Kaiser Alexander I. Reval, 1902. - On the general influence of Professor Parrot on university reform in Russia, see: Andreev A. Yu. Imperator Aleksandr I i professor G. F. Parrot: k istorii vozniknoveniia "universitetskoi avtonomii" v Rossii // Otechestvennaia istoriia. 2006. No. 6. P. 19-30.

7 Drafts of letters from G. F. Parrot to Emperor Alexander I are kept in the Latvian State Historical Archives (Latvijas Valsts vēstures arhìvs, abbreviated LVVA). I express my sincere gratitude to A. Yu. Andreyev for providing transcripts of the of these letters which are being prepared for publication.

${ }_{8}$ Pis'mo G. F. Parrota imperatoru Aleksandru I ot 13 noiabria 1804 g. // LVVA. F. 7350. Op. 1. D. 6. L. 96.

9 Pis'mo G.F. Parrota imperatoru Aleksandru I ot 11 dekabria 1804 g. // Ibid. F. 4060. Op. 1. D. 1084. L. 15-18. 
Estonian" should be carried out only in "spirit of the nation" in order to remain faithful to enlightened laws in it. This direction of education could not be given by the local nobility; this was possible only under the control of the university. It was the main problem that the Dorpat professor could solve only with the help of the tsar: Parrot really wanted to transfer the leadership of parish schools from the landowners to the university. The Dorpat district was the only educational district of all where the conflict between the school commission of the university and the nobility was most pronounced: members of the commission insisted on their right to manage the gymnasiums, county and parish schools of the district, whereas the Baltic nobility did not want to lose control over the educational institutions they funded ${ }^{10}$.

The question of the development of primary education in the district became one of the central topics of the extensive correspondence between Alexander I and the German scholar, which was evidence of a trusting relationship that "connected the autocratic ruler of the huge empire and one of his subjects who used this connection not for personal gain but tried to give impetus to the most important transformations aimed at improving the condition of the whole country"11. This set of documents introduced for the first time into scholarship enables to trace the outbreak of the struggle around Emperor Alexander I on the question of the need for establishing a special system of parish schools in the Dorpat district.

To solve his question, the Dorpat professor arrived in Petersburg in January 1805. Already during the first audience, he presented to the tsar a project on the establishment of parish schools ${ }^{12}$, which involved the division of lower schools in the district into two levels: initial or village schools, run and maintained at the expense of landowners; and parish schools, which had to admit capable students from the former. Teachers of parish schools and their assistants were appointed and approved by the university, and members of the Dorpat School Commission had the right to inspect "not only parish, but even village primary schools"13. In addition, the author of the project assigned funding for parish schools to the treasury.

It was important to Professor Parrot that a new type of lower school, not indicated in the Preliminary Rules and School Charter of 1804, emerged in the district. Thus, it was possible to bring primary education under the control of the university to ensure its maintenance at the expense of the state funds while to formally retain the already approved control of village primary schools run by landowners. Moreover, friendly relations with the emperor allowed to hope for the approval of the financial side of the issue. The maintenance of 279 rural and 56 urban parish schools, as well as the three-year maintenance of five seminaries for teacher training had to cost the state 103800 rubles per year, i. e. actually comparable to the cost of founding another university!

${ }^{10}$ For more information on the failed reform of the parish schools in the Dorpat district, see: Gracheva Yu.E. K voprosu ob ustroistve prikhodskikh uchilishch v Derptskom okruge // Vestnik PSTGU. Seriia II: Istoriia. Istoriia Russkoi Pravoslavnoi Tserkvi. 2017. No. 74. P. 85-92.

11 Andreev A.Yu. Perepiska imperatora Aleksandra I i professora G. F. Parrota (1802-1825) kak istochnik po izucheniiu politicheskikh reform v Rossiiskoi imperii // Vestnik PSTGU.Seriia II: Istoriia. Istoriia Russkoi Pravoslavnoi Tserkvi. 2019. No. 89. P. 67-82.

12 Uchrezhdenie prikhodskikh uchilishch // Rossiiskii gosudarstvennyi istoricheskii arkhiv (RGIA). F. 732. Op. 1. D. 275. L. 32-45 ob.

13 Ibid. L. 35. 
Emperor Alexander listened favorably to the professor from Dorpat and probably promised him his support, which encouraged and delighted Parrot. His letter to the tsar was filled with glee, "Your inexpressible kindness to parish schools made me lose my head"14. Parrot hoped that the case for which he came to St. Petersburg would be resolved quickly, and it was only necessary to wait for a meeting of the Main Directorate of Schools and to get a formal approval from the minister. But this was not so easy to achieve.

Parrot was extremely emotional in perceiving both successes and failures in his path. The feeling of happiness was quickly replaced by impatience ("je me consumption de dépit") at the slightest delay, and then again - with joy when it seemed to him that the issue was almost resolved. It should be pointed out that Parrot's disappointment was justifiable. Time passed, but the question of parish schools at meetings of the Directorate had not been raised for a long time - members of the Directorate gathered on January 12, and then on January 26, but the topic of parish schools was not included in the agenda. The personal meeting with the Minister of Education, Count P. V. Zavadovsky, also ended unsuccessfully since the date of the next meeting of the Directorate was postponed for a week, and it was not clear whether the burning question for Parrot would be discussed. "I asked him, begged to change this arrangement. He answers me: "You have your right to take back your pecuniary affairs..." And parish schools? said I to him. - "Well, you must wait" - These deadlines make me neglect many of my duties in Dorpat. - "Wait". I stared at him for half a minute. It was in vain, I left him"15.

The correspondence between Emperor Alexander and Professor Parrot introduced into scholarship not only sheds more light on their character traits and worldview, but also enables to extend knowledge about the activities of the Ministry of Public Education in the first decade of the $19^{\text {th }}$ century, in particular, to clarify in more detail the course of meetings of the Main Directorate of Schools, whose journals of proceedings do not always give a complete picture. So, probably, Parrot's persistence forced the minister to begin discussing the issue of parish schools in the Dorpat district informally (since the issue was not mentioned in the journal of proceedings of the Directorate meeting of February 14, 1805), and the superintendent of the district F. I. Klinger was able to familiarize colleagues with the Parrot project at this meeting. The Dorpat professor hastened to share his joy with the tsar :"Les affaires de l'Université sont en bon chemain au directoire et c'est encore à mon Alexandre, à Lui seul que je le dois. On a accordé les écoles paroissiales, sauf une seconde révision; c'est beaucoup de gagné. Klinger a parlé à cette occasion bien selon mon cœur. Il a été tombé à la lecture. Le tout lui a beaucoup plu, et sur le champ il s'est déclaré fortement pour la chose et a emporté les suffrages" 16 .

It should be mentioned that Parrot, being unable to attend meetings of the Directorate without a special invitation, received all the necessary information from the trustee of the Dorpat school district Friedrich Maximilian Klinger (in Russian citizenship - Fedor Ivanovich) despite the fact that Parrot was subordinate to Klinger in the service hierarchy.

14 Pis'mo G.F. Parrota imperatoru Aleksandru I ot 8 ianvaria 1805 g. // LVVA. F.7350. Op.1. D. 6. L. 134.

15 Pis'mo G. F. Parrota imperatoru Aleksandru I ot 9 fevralia 1805 g. // Ibid. L. 126.

16 "The affairs of the University progress well at the Directorate and it is still to my Alexandre alone that I owe it. Parish schools were approved, except for a second revision; we've won a lot. Klinger spoke on this occasion well according to my heart. He started reading. The whole thing pleased him very much, and on the spot he declared himself strongly for the subject and won the votes" (Pis'mo G. F. Parrota imperatoru Aleksandru I ot 18 fevralia 1805 g. // Ibid. L. 129). 
In controversial matters, Klinger not only had to support the rector but also to serve as "a certain buffer that mitigates clashes between the university and the ministry"17. In a situation when Parrot wanted approval of a draft contrary to the already adopted decrees, Klinger's firm voice in the Directorate was necessary for him. The same was understood by Emperor Alexander: "It is urgent that You notify Klinger and communicate to him the Plan, which You have presented to me so that he will be absolutely on our side, when the Minister speaks to him"18. As it has already been noted in the literature, the emperor, trying to help Parrot in formal institutions, did not recourse to his unlimited power, but, on the contrary, kept a low profile in every possible way leaving the defense of his own opinion to other officials ${ }^{19}$.

The results of the next meeting of the Directorate made Parrot exult. For some reason, the journal of proceedings of the Directorate for February 23, 1805 did not report on the discussion of the issue of parish schools, but the professor himself was sure that the work of his whole life was nearing completion. "Les écoles paroissiales sont décretées! Dans 8 jours le Ministre les présentera à Votre Sanction... Que je suis heureux!"20 he exclaims in a letter to the tsar on the following day. However, Parrot was clearly in a hurry his project in the present form did not satisfy the members of the Directorate, and count P. A. Stroganov proposed to curtail the project so that it would be a general plan for parish schools of all provinces of the Dorpat district, "and an additional charter was subsequently composed for each province separately" 21 . But this delay was far from the last. As an exception, the professor from Dorpat was invited to a meeting on March 2 where he was offered to read out an amended version of the $\mathrm{draft}^{22}$, but the reaction of the audience was clearly not in favor of Parrot. Firstly, the minister was dissatisfied with the amendments made ${ }^{23}$; secondly, the objections were caused by the allocation of a fixed amount to parish schools of the Dorpat district, which put him in an exceptional position compared to other the university districts. Finally, the very presence of Parrot at the Directorate meeting posed difficulty for the minister: the emperor's friendship with the Dorpat rector was well known, but at the same time created a dangerous precedent and violated the existing order, when only the trustees had the right to represent various university projects in the

17 Gavrilina I. A. Rektor G. F. Parrot i popechitel' F. M. Klinger: dva vzgliada na razvitie Derptskogo universiteta v pervye gody ego sushchestvovaniia (1802-1803) // Klio. 2017. No. 10. P. 47-56.

18 Pis'mo imperatora Aleksandra I G. F. Parrotu posle 1 fevralia 1805 g. // LVVA. F. 7350. Op. 1. D. 6. L. 7-13 ob., 29-35.

19 Andreev A. Yu. Perepiska imperatora Aleksandra I i professora G. F. Parrota... P. 77.

20 "Parish schools are approved! In 8 days the Minister will present them to Your Sanction... I am so happy!" (Pis'mo G. F. Parrota imperatoru Aleksandru I ot 24 fevralia 1805 g. // LVVA. F. 4060. Op. 1. D. 1084. L. $14-14$ ob.).

${ }^{21}$ Pis'mo G. F. Parrota v Glavnoe Pravlenie uchilishch ot 7 marta 1805 g. // RGIA. F. 732. Op. 1. D. 275. L. $49 \mathrm{ob}$.

22 The archive preserved this version of the plan in German - Parrot did not know Russian and could not read documents in it at the meeting of the Directorate. When he needed to provide papers to the emperor or minister, he had to ask the translator for help (Ibid. L. 14-31 ob.).

${ }^{23}$ G. F. Parrot described to the king his conversation with the minister: «On me fit de nouveau la lecture; et à mon grand étonnement on me reprocha de n'avoir pas exécuté l'ordre qu’on mavoit donné. Je nommai le contenu de quelques articles que j’avois biffés. Alors le Ministre me dit que ce nétoit pas ce que jaurois dû faire; que j’avois dû présenter non un règlement détaillé, mais simplement un plan qui ne contient que les points généraux; que le règlement ne pourroit se faire que lorsqu’on aurroit levé toutes les difficultés de détail par l'intervention des autres autorités» (Letter from Pis'mo G. F. Parrota imperatoru Aleksandru I ot 10 marta 1805 g. // LVVA. F. 7350. Op.1. D. 6. L. 127-127 ob.). 
Main Directorate of Schools. To avoid this in the future, the Directorate decided "that the university itself should not send deputies to the Main Directorate of Schools without special permission $»^{24}$.

The disapproval of the Parrot project by members of the Directorate was most fully expressed by the trustee of the St. Petersburg school district N. N. Novosiltsev in a special note. He sharply criticized the division of parish schools into two levels, the requirements for landowners to send capable people to become teachers, the opening of special seminaries, and most importantly, an attempt to offload maintenance costs of schools onto the treasury: "The government needs to encourage the owners to establish parish schools in the villages, and to support them, it can allocate a certain amount (up to 10 or 15 thousand rubles) and transfer it to the special disposal of the Ministry of Education and officials dependent on it, but in this case, it should not determine in any way either permanent income, or the number of employees to maintain"25. Novosiltsev's logic was clear: why make changes to the already adopted decisions? The four-stage system of educational institutions was only recently formed, and Parrot proposed the introduction of a new stage, which also required additional and very significant costs. As a result, the minister decided to draw up his own project, in which local authorities were entrusted with maintenance of the parish schools of the Dorpat district, and only teacher training seminaries remained subsidized by the state. The draft of minister met with approval by the members of the Directorate, and together with the highest report was presented to Emperor Alexander I on March 25, 1805. Novosiltsev's special opinion "that the seminaries shouldn't be fully funded by the state" was supported by the trustees of the Vilnius and Kharkov educational districts, Prince A. A. Czartoryski and Count S. O. Potocki, as well as Counts P. A. Stroganov and P. S. Svistunov.

Every day, Parrot's mood was getting worse. He had planned to come to St. Petersburg for a month and to deal with the issue with schools during this time, but time went on, and the matter remained unsolved. He used various attempts of putting emotional pressure on the emperor: he suggested that he publish in the "Hamburg newspaper" information about the imminent opening of parish schools in Dorpat (which had not yet been approved by the ministry! $)^{26}$; in each letter he described the benefits that this proposal would bring $^{27}$; he asked him to support the project during the weekly reports of the minister ${ }^{28}$. But the emperor was silent. Only at the beginning of April 1805, Parrot received a brief note from Alexander, in which the emperor urged the professor from Dorpat to be patient: "J'ai reçu du Ministre le plan pour les écoles, et avec une oppinion différente de plusieurs membres. Je suis à examiner le tout dès que la chose sera terminée, elle ne souffira plus de

${ }^{24}$ Zhurnal Glavnogo pravleniia uchilishch ot 2 marta 1805 g. // RGIA. F. 732. Op. 1. D. 4. L. 61.

${ }_{25}$ Mnenie Popechitelia Sankt-Peterburgskogo okruga Novosil'tseva na proekt g. Parrota o zavedenii prikhodskikh uchilishch v okruge Derptskogo Universiteta // Ibid. D. 275. L. 73 ob. - 74. $128 \mathrm{ob}$.

${ }^{26}$ Pis'mo G. F. Parrota imperatoru Aleksandru I ot 1 marta 1805 g. // LVVA. F. 7350. Op. 1. D. 6. L. 128-

27 "Voyez la nombreuse jeunesse de trois nations opprimées s'instruire à devenir les soutiens de la félicité publique et consiler la génération présente des maux qu’elle a soufferts. O combien de bénédictions, de vœux, de prières ne séleveront pas vers le ciel des cabanes du pauvre cultivateur pour leur ange tutelaire!" (Pis'mo G. F. Parrota imperatoru Aleksandru I ot 24 fevralia 1805 g. // LVVA. F. 4060. Op. 1. D. 1084. L. 14$14 \mathrm{ob}$.).

28 Pis'mo G. F. Parrota imperatoru Aleksandru I ot 18 marta 1805 g. // Ibid. L. 21. 
retard. Vous vous trompez beaucoup de me voir couroucé; sans lêtre le moins du monde je suis ennemi declaré du desordre et voilà tout» ${ }^{29}$.

Alexander I did not want to violate the established order and solve issues bypassing the Ministry of Public Education. The situation was much more serious. The country was on the verge of war with Napoleon; negotiations on the creation of an anti-French coalition had been underway since the end of 1804 . N. N. Novosiltsev, who did a lot to conclude a treaty between Russia and Great Britan in St. Petersburg on March 30, 1805, was especially active in foreign affairs, and immediately afterwards began preparing for negotiations with the French government ${ }^{30}$. Naturally, Novosiltsev in March-April had constant access to the tsar, which Parrot had long been deprived of ${ }^{31}$. For fear that the emperor would take Novosiltsev's side in the issue of parish schools, Parrot first tried to convince the St. Petersburg trustee personally to withdraw his objections to the project. When this failed, and Parrot was forced to admit that for the first time his view was polar opposite to that of Novosiltsev, he sent Alexander another letter with detailed criticism of the special opinion ${ }^{32}$. But this did not seem enough for Parrot. He felt insecure, because the plan for the establishment of parish schools had been on the desk of the tsar for three weeks (though not in its original version, but in ministerial), and the matter had not been dealt with. Trying to push the emperor to make a decision, Parrot demanded " put me against him (Novosiltsev) in Your presence; if I am wrong I will be the first to yield to him; I can only want public good ${ }^{33}$. Of course, the professor from Dorpat hoped that as soon as he was in front of the emperor, even if Novosiltsev was nearby, the case would be solved in his favor. Parrot, of course, was not going to abandon his project.

And Alexander made a decision. On 17 April 1805, the emperor sent Parrot a ministerial project and Novosiltsev's objections to it with a request to read them and express his opinion. Although there was no hint in the letter that the emperor would support Parrot ("You will see that all commonly reject the plan to take the parish schools at the expense of the government. The cited reasons are very delicate, especially in the position where I am. You will also see that Novosiltzof's opinion is not exactly what you tell me in your letter, some of the reasons he cites are quite strong" $\left.{ }^{34}\right)$, he was happy ${ }^{35}$. Having received the letter, he did not waste a minute and worked all night, translated the minister's plan into French, wrote a refutation to it, and by morning prepared a new message to a "dear friend". But he knew inside that he would have to make certain concessions. In the next couple of days Parrot proposed to draw up a new project in which he promised to shift the

29 "I received from the minister the plan for schools, and with a different opinion from several members. I need to examine everything as soon as it is over, it will no longer be delayed. You are very mistaken to consider me angry; I am not angry by any means. I am the enemy of disorder, and that's all" (Pis'mo imperatora Aleksandra I G. F. Parrotu posle 4 aprelia 1805 g. // LVVA. F. 7350. Op. 1. D. 6. L. 7-13 ob., 29-35).

30 "The sovereign believed that no one could fulfill such an order better than him" // Bogdanovich M. I. Istoriia tsarstvovaniia imperatora Aleksandra I i Rossii v ego vremia: v 6 t. T. 1. St. Petersburg, 1869. P. 367.

31 Their last personal meeting took place on February 4, 1805.

32 Pis'mo G. F. Parrota imperatoru Aleksandru I ot 13 aprelia 1805 g. // Ibid. L. 119-121.

33 Ibid.

34 Pis'mo imperatora Aleksandra I G. F. Parrotu ot 17 aprelia 1805 g. // LVVA. F.7350. Op.1. D. 6. L. 7-13 ob., 29-35.

35 Parrot's letter to the emperor on April 18, 1805 began as follows: "The Guardian angel of humanity! You brought hope back to my sorry heart. I thank you with all my soul, on behalf of the 9/10 of Your subjects - of Your brothers. We are triumphant" (Pis'mo imperatora Aleksandra I G. F. Parrotu ot 18 aprelia 1805 g. // Ibid. L. 117-118). 
burden of maintaining parish schools from the treasury to local authorities, primarily to public charity.

Did Emperor Alexander need this concession? Every day the economic situation of the country deteriorated; inflation began. In a situation where the emperor was waiting for subsidies from Britain to start a war, it was impractical to spend significant funds on parish schools in the Dorpat district. Moreover, most members of the the Main Directorate of Schools supported the opinion of Novosiltsev and did not intend to make any changes to the already existing school charter. Alexander hardly wanted to put his personal interest in this issue before the rather unified position of the members of Directorate. Therefore, the letter with the papers, which so delighted Parrot, meant not only a reluctance to enter the controversy, not only an evident departure from resolving the issue in question, but also a kind of recognition that Parrot's case was lost. The Dorpat rector himself did not want to admit this for a long time. It seemed to him that this was a matter of several days or even hours ("I will take a few hours off to regain some strength while waiting for Your order"36), but time went on, and Alexander was silent.

The tone of the letter he wrote two weeks later was completely different. Sending an updated project of parish schools, Parrot demanded that the emperor pay attention: "Sire! je Vous supplie de mentendre encore une fois, la dernière fois!", lamented that "quatre mois de mon existence écoulés sans gain pour le bien public!!!", and at the end of the letter, emotions completely overwhelmed him - Parrot dared be rude to Alexander! "Mes motifs sont purs comme votre volonté, et voilà pourquoi jose me mettre entre Vous et Vos alentours, et demander que ma voix, placée dans la balance de Votre équité, pèse autant que la leur" 37 - he wrote to the tsar, demanding that he should be equated with Novosiltsev. Parrot was beginning to realize that the emperor supported Novosiltsev, and all attempts to emphasize his personal friendly relationship with the tsar ended unsuccessfully. State affairs for Alexander, naturally, were of primary importance, especially since Novosiltsev played a decisive role at that moment - it was he who was entrusted with negotiations with the English government to provide subsidies for the war.

And only after another desperate letter from Parrot did Alexander decide to break his silence. On May 11, their third meeting took place in 1805, during which the emperor agreed to transfer the new plan of parish schools to the minister for discussion in the Directorate, and also made it clear to Parrot that this issue could still be resolved positively. But even Parrot realized that this consent was obtained under pressure: "Au moment oú Vous Vous décidâtes je crus sentir, quoique confusément que Vous nétiez pas heureux [The emperor avoided a decisive move; he did not want to break friendly relations with the professor from Dorpat, but also did not want to make big promises]" ${ }^{38}$.

On May 18, a regular meeting of the Main Directorate of Schools was held. There, the members of the Directorate, comparing the ministerial project and the second project of Parrot and pointing out the difference between them, decided to send the ministerial project to "respect the noble and urban societies of the University of Dorpat

${ }^{36}$ Pis'mo imperatora Aleksandra I G.F. Parrotu ot 18 aprelia 1805 g. // LVVA. F. 7350. Op. 1. D. 6. L. 118.

37 "My motives are as pure as your will, and that is why I dare put myself between you and your circle, and ask that my voice thrown in the scale weigh as much as theirs" (Pis'mo G. F. Parrota imperatoru Aleksandru I ot 1 maia 1805 g. // Ibid. L. 115-115 ob.).

38 Pis'mo G. F. Parrota imperatoru Aleksandru I ot 15 maia 1805 g. // Ibid. L. 109-109 ob. 
district" ${ }^{39}$. The question was once again postponed, and this time for a rather long time. G. F. Parrot had to return to the University of Dorpat, where at the end of May he was again elected its rector, and expected his issue to be to resolved.

He had to wait for a long time, which was completely out of his character. Parrot often tried to remind the emperor of the unresolved issue with parish schools, asked permission to open at least seminaries for teacher training in order to get the project off the ground, actively looking for land for these seminaries. Fearing that Alexander, having learned about the objections of the Livonian nobility and consistories who did not want to lose control of parish schools, would finally postpone the implementation of his project, he tried to convince the emperor that it was possible to reach an agreement with consistories and that work was already underway in this direction. Parrot also did not miss an occasion to complain to the tsar about his deteriorating health: "This spring my health suffers more than ever and I do not want to leave You, o my Alexander, before I have finished" 40 . When he could no longer bear waiting for an answer from the emperor, Parrot fell into despair: "si on parvient à ruiner le plan des écoles paroissiales, javoue que je perdrai tout interret aux écoles de toute espèce, j’abhorrerai tout ce que jai fait dans cette partie" 41 . Here Parrot reminded of his contribution to transformations of gymnasiums and county schools of the Dorpat school district under the new charter. Despite the fact that the district consisted of only four provinces and was the smallest in comparison with the rest of the educational districts, this transformation was an important step in the course of public education reforms of the early $19^{\text {th }}$ century.

Alexander could not help but thank the members of the School Commission of the University of Dorpat. In December 1806, the emperor awarded the Order of St. Vladimir of IV degree to Professor G. F. Parrot, and the remaining professors were awarded with gifts. At the same time, Parrot was allowed to come to St. Petersburg, which contributed to the beginning of a new stage in the discussion of the issue of parish schools.

Parrot arrived in St. Petersburg at the end of December 1806 and probably expected that Alexander I would immediately set a day for their meeting. But a whole month passed until the professor got the opportunity to see the emperor personally. Parrot did not give up hope that in addition to the award for the transformation of gymnasiums and county schools, he would receive the final consent of the tsar to carry out his project of parish schools. To do this, it was necessary not only to overcome the resistance of the members of Directorate, but also to convince the emperor to act decisively. After all, Parrot was well aware that if Alexander firmly supported his project, then the minister would have to agree with this. "Parish schools alone can proclaim liberty without a revolution and without massacres" 42 , he wrote to the emperor knowing very well how important peace in the Empire was for the sovereign, especially during the ongoing hostilities. Several proposals were put forward so that Alexander was not surprised by the disapproving opinion of the members Directorate. Firstly, Parrot suggested the approval of his project by Zavadovsky

39 Vypiska iz zhurnala Glavnogo Pravleniia uchilishch ot 18 maia 1805 g. // RGIA. F. 732. Op. 1. D. 4. L. 126 ob.

40 Pis'mo G. F. Parrota imperatoru Aleksandru I ot 16 marta 1806 g. // LVVA. F.7350. Op.1. D.7. L. 18-19.

41 "If the ruining of the plan for the parish schools succeeds, I confess that I will lose all interest in schools of all kinds, I will abhor everything I have done in this part" (Pis'mo G. F. Parrota imperatoru Aleksandru I posle 19 maia 1806 g. // Ibid. L. 20-22).

${ }^{42}$ Pis'mo G. F. Parrota imperatoru Aleksandru I ot 12 ianvaria 1807 g. // Ibid. L. 45-45 ob. 
should not be necessary at all since a year and a half had passed since the ministerial project was sent to the province (a project that was not agreed either with him, or with the university), and the answer came only from the Sejm of the Livonia province, which made it possible not to take into account the opinion of the local nobility. Secondly, Parrot was ready to present at the Directorate meeting, if necessary, his note on the measures taken by the university to establish parish schools, having previously deleted from it "all the truths that can irritate as well as the main proposal concerning the means of performance" 43 . This note was indeed read by Parrot at the February 28 meeting of the Directorate, where he was personally invited ${ }^{44}$. A week prior to this, another meeting between Alexander and Parrot took place, at which the professor asked permission to draw up a third edition of his project to clarify some inconsistencies. The new plan emphasized the need for general inspection by the university of all rural schools, the number of which was not specified because it was "was not given to the University with all possible accuracy" ${ }^{2}$. The way teachers were taught had changed; however, Parrot did not explain exactly how, specifying only that it would be "much better and less expensive". The landowners were obliged to allow capable peasants to study, freeing them from recruiting duty, and students of city schools had to make an additional annual contribution to pay to the teacher. While Parrot expected the sovereign's approval of these changes, the question of parish schools in the Dorpat district was again raised at a meeting of the Main Directorate of Schools, whose members having familiarized themselves with the papers received from the Livonian nobility, decided to once again submit to the tsar their draft of parish schools approved on May 18, 1805.

It is worth noting that Parrot, although he was present at this meeting, interpreted its results in a rather peculiar way. On the following day, in a letter to the tsar, he wrote: "As for the parish schools, it was agreed that they should be implemented, without objecting to the lack of official response from the three governments" 46 . Perhaps the professor simply did not attach any importance to this meeting because he believed that after the formal consent of the Directorate to any draft of parish schools, the emperor could simply sign his project, the approval of which (as Parrot constantly emphasized in the letters) was received long ago. There remained just a small matter: it was necessary to meet again with Alexander, to hand him the third edition of his plan, to see how the sovereign would sign it, and to wait for an official copy from the minister to be kept at university. But Parrot again rushed to conclusions.

The next report from the Minister of Education addressed to the of the tsar was supposed to be delivered on Saturday, March 9. The professor from Dorpat begged Alexander several times in writing for their meeting to take place before the minister arrived. The only time the emperor could afford to discuss the issue was early Saturday morning. All their previous meetings had taken place in the evenings - Alexander could freely devote time to his friend; at the same time, the tsar was constantly distracted. After Parrot had left his next project in the sovereign's office, he could not get rid of his anxiety: "I don't know

${ }^{43}$ Pis'mo G. F. Parrota imperatoru Aleksandru I ot 25 ianvaria 1807 g. // LVVA. F. 7350. Op. 1. D. 7. L. $47-47$ ob.

44 Parrot G. F. Nachertanie o prikhodskikh uchilishchakh okruga Derptskogo universiteta // RGIA. F. 732. Op. 1. D. 6. L. 44-48 (in French); Ibid. D. 275. L. 105-107 ob. (in Russian).

45 Pis'mo G. F. Parrota imperatoru Aleksandru I ot 20 fevralia 1807 g. // LVVA. F.7350. Op. 1. D.7. L. 55-55 ob.

${ }^{46}$ Pis'mo G. F. Parrota imperatoru Aleksandru I ot 1 marta 1807 g. // Ibid. L. 60-60 ob. 
if the plan is copied, if You signed it, if the Minister received it, if the rescript for my trip exists" ${ }^{\prime 7}$. The professor's concern was not groundless. The emperor did not sign Parrot's project, but handed it over to Zavadovsky with an urgent request to compare it with the ministerial project sent out in the summer of 1805 for discussion in the province of the Dorpat district. The minister fulfilled the highest order, and a few days later a new report was sent to Alexander. The minister, outlining the main differences between the two plans and concluding that it was inconvenient to accept Parrot's new plan, returned it to the $\operatorname{tsar}^{48}$. The members of the Directorate did not participate in the discussion of the third Parrot's project, while the ministerial draft was again presented at the regular meeting held on March 14, which they submitted for the fourth (!) time approved and signed "for submission to the Sovereign Emperor", not forgetting to mention again the special opinion of N. N. Novosiltsev and other trustees regarding the state financing of seminaries ${ }^{49}$. A copy of the said report, preserved in the archive, is not dated, but it is safe to assume that the report was written by Zavadovsky between March 9 and $14-$ the Saturday report of the minister, when he received from the hands of the emperor the third draft of Parrot, and the meeting of the Directorate on March 14.

As a result, the period of Parrot's stay in St. Petersburg in 1807 was as unsuccessful as in 1805. On March 16, Alexander I left the capital for the army. Parrot was informed the day before that at a meeting of the Directorate the plan of parish schools was signed. But what was his surprise when, at a meeting with the tsar on the day of his departure, he saw an unsigned third edition of his project. The professor from Dorpat was perplexed: «I do not know if the plan that the Minister let circulate for signature is the true one (presumably it is not, because You still had it at the time of Your departure, I do not know if You gave to him the true plan, the one that You corrected Yourself, and if You signed it beforehand to prevent obstacles» (“j'ignore si le plan que le Ministre a fait circuler pour la signature est le vrai (vraisemblablement ce ne l'est pas, car Vous l'aviez encore le moment de Votre départ, j’ignore si Vous le lui avez donné le plan vrai, celui que Vous avez corrigé Vous-même, et si Vous l'avez signé préalablement pour prévenir les obstacles") ${ }^{50}$. Parrot had to leave Petersburg with "a dagger in the heart", without a rescript, without an official approval of his plan and, accordingly, without the possibility of obtaining state funds for the foundation of seminaries for the training of teachers of parish schools.

In correspondence with the tsar, Parrot raised the question of the construction of parish schools in the Dorpat district more than once. In the summer of 1807, during their personal meeting in Valmiera, soon after the signing of the Treaties of Tilsit, the emperor again encouraged Parrot.

Having learnt that the university had already found land for seminaries and was waiting for official documents, Alexander confirmed that they «had to continue taking the necessary measures without worrying about the delay of the expected decree", which was

47 Pis'mo G. F. Parrota imperatoru Aleksandru I ot 13 marta 1807 g. // LVVA. F. 7350. Op. 1. D. 7. L. 64.

48 This is probably why the third edition of Parrot's draft was not preserved in the archives since it was only for a short time with the minister, and was not included in the Directorate. The main ideas of this edition are reconstructed from Parrot's letter to Alexander dated February 20, 1807 and the March report of P. V.Zavadovsky.

49 Zhurnal Glavnogo pravleniia uchilishch ot 14 marta 1807 g. // RGIA. F. 732. Op. 1. D. 6. L. 67.

${ }^{50}$ Pis'mo G. F. Parrota imperatoru Aleksandru I ot 17 marta 1807 g. // LVVA. F.7350. Op. 1. D. 7. L. 66-66 ob. 
supposed to be issued immediately after the return of the emperor to Saint Petersburg ${ }^{51}$. But the University of Dorpat never received any decree. Further requests, prayers and demands from the professor remained unanswered until 1809, after which the issue of parish schools was no longer touched upon in their correspondence.

So, the reform of parish schools in the Dorpat school district did not take place. The issue was discussed in detail in the Main Directorate of Schools, was supported by the Minister of Education, had his own "lobbyist" - Professor Parrot, but did not receive final approval of Alexander I. It turned out that the exceptional attention that the emperor paid to educational reforms at the beginning of his reign did not last long, and by 1805 the tsar began to lose interest in educational projects. Even the persistence of the two main ideologists - G. F. Parrot and P. V.Zavadovsky - who repeatedly offered the emperor their projects for signature, could not induce Alexander to decisive actions. In fact, from the beginning of 1805, the emperor did not want and could not engage in education - at first, he was prevented from preparing for the conclusion of a coalition, then the two-year war and the worst financial crisis did not allow him to spend significant funds on the transformation of the already built system of educational institutions.

\section{References}

Andreev A. Yu. Correspondence of Emperor Alexander I and Professor G. F. Parrot (1802-1825) as a source for the study of political reforms in Russian Empire. Vestnik PSTGU. Seriia II: Istoriia. Istoriia Russkoj Pravoslavnoj Cerkvi, 2019, iss. 89, pp.67-82. (In Russian)

Andreev A. Yu. Emperor Alexander I and Professor G. F. Parrot: concerning the origin of "university autonomy" in Russia. Otechestvennaia istoriia, 2006, no. 6, pp. 19-30. (In Russian)

Andreev A. Yu. F.-S. Laharpe and the elaboration of the reform of elementary education in Russia. Rossiiskaia istoriia, 2010, no. 6, pp. 40-46. (In Russian)

Bogdanovich M. I. The history of the reign of Emperor Alexander I and Russia in his time. St. Petersburg, Tip. F. Sushchinskago Publ., 1869, vol. 1, 382 p. (In Russian)

Gavrilina I.A. Rector G.F.Parrot and curator F.M.Klinger: two views on the development of Dorpat University in the early years of its existence (1802-1803). Klio, 2017, no. 10, pp.47-56. (In Russian)

Gracheva Ju.E. To the question about the structure of parochial schools in the district of Dorpat. Vestnik PSTGU. Seriia II: Istoriia. Istoriia Russkoj Pravoslavnoj Cerkvi, 2017, iss. 74, pp. 85-92. (In Russian)

Kuzber Ia. The upbringing of the elites and public education in the Russian Empire in the $18^{\text {th }}-$ first half of the $19^{\text {th }}$ century. Discourse, legislation, reality. Moscow, Politicheskaia entsiklopediia Publ., 2018, 613 p. (In Russian)

Rei M.-P. Alexander I. Moscow, ROSSPEN Publ., 2013, 495 p. (In Russian)

Rozhdestvenskii S. V. Historical review of the activity of the Ministry of Public Education. St. Petersburg, Izd. Ministerstva Narodnogo Prosveshcheniia Publ., 1902, 785 p. (In Russian)

Shil'der N. K. Emperor Alexander I, his life and reign. Vol.2. St. Petersburg, Izd. A.S. Suvorina Publ., 1897, 409 p. (In Russian)

Zhukovskaia T.N. Enlightement projects of "young friends" and formation of the Department of National Education (1802). Trudy istoricheskogo fakul'teta Sankt-Peterburgskogo universiteta, 2012, no.11, pp. 181-191. (In Russian)

Статья поступила в редакцию 3 ноября 2020 г. Рекомендована в печать 12 марта 2021 г.

Received: November 3, 2020

Accepted: March 12, 2021

${ }^{51}$ Pis'mo G. F. Parrota imperatoru Aleksandru I ot 11 avgusta 1807 g. // LVVA. F. 7350. Op. 1. D. 7. L. 77-77 ob. 